\title{
Lentinus crinitus basidiocarp stipe and pileus: chemical composition, cytotoxicity and antioxidant activity
}

\author{
Míria B. D. Bertéli ${ }^{1}$. Olavo B. Q. Oliveira Filho ${ }^{1}$. Janyeli D. S. Freitas ${ }^{1}$. Wanessa C. Bortolucci ${ }^{1}$. Gustavo R. Silva ${ }^{2}$. \\ Zilda C. Gazim ${ }^{1}$ - Francislaine A. R. Lívero ${ }^{2}$ Evellyn C. W. Lovato ${ }^{3}$. Juliana S. Valle ${ }^{1}$. Giani A. Linde ${ }^{1} \cdot$ Lillian Barros $^{4}$. \\ Filipa S. Reis ${ }^{4} \cdot$ Isabel C. F. R. Ferreira ${ }^{4} \cdot$ Luzia D. Paccola-Meirelles $^{1} \cdot$ Nelson B. Colauto $^{1}$ (I)
}

Received: 24 September 2020 / Revised: 3 March 2021 / Accepted: 6 March 2021 / Published online: 22 March 2021

(c) The Author(s), under exclusive licence to Springer-Verlag GmbH Germany, part of Springer Nature 2021

\begin{abstract}
Lentinus crinitus is a wild fungus, which produces mushrooms consumed by some Amazonian Indians. Besides, it is recognized for its diverse biological activities and biotechnological applications. However, there are few reports with limited information on basidiocarp chemical composition and cytotoxicity. Our study determined and evaluated the chemical composition, cytotoxicity, and antioxidant activity of $L$. crinitus pileus and stipe separately. Chromatographic methods were used to evaluate basidiocarp chemical composition. Cytotoxicity was verified using a cell culture from porcine liver and against a panel of human tumor cells from different models. Antioxidant activity was assessed by different in vitro methods. The pileus had higher levels of protein, ash, tocopherols, and organic acids, mainly malic acid, than the stipe. The stipe revealed higher contents of carbohydrates, energy, soluble sugars, and phenolic acids, mostly $p$-hydroxybenzoic acid. L. crinitus basidiocarp has mainly trehalose as soluble sugar, and less than $1 \%$ fat being $~ 60 \%$ polyunsaturated fatty acids (mostly linoleic and oleic acids), and $\sim 13 \%$ saturated fatty acids (mostly palmitic acid). L. crinitus revealed high antioxidant activity for most methods and no cytotoxic activity against tumor and non-tumor cells. L. crinitus basidiocarp can be considered a functional food with applicability in food, cosmetic, and pharmaceutical industries.
\end{abstract}

Nelson B. Colauto

nelsonbcolauto@gmail.com

1 Laboratory of Molecular Biology, Graduate Program in Biotechnology Applied to Agriculture, Universidade Paranaense, Praça Mascarenhas de Moraes, 4282, Umuarama, PR, P.O. Box 224, 87.502-210, Brazil

2 Laboratory of Preclinical Research of Natural Products, Graduate Program in Medicinal Plants and Phytotherapics in Basic Attention, Graduate Program in Animal Science with Emphasis on Bioactive Products, Universidade Paranaense, Umuarama, PR, Brazil

3 Laboratory of Neurosciences, Graduate Program in Medicinal Plants and Phytotherapics in Basic Attention, Universidade Paranaense, Umuarama, PR, Brazil

4 Centro de Investigação de Montanha (CIMO), Instituto Politécnico de Bragança, Campus de Santa Apolónia, Bragança 5300-253, Portugal 


\section{Graphic abstract}

\section{Lentimus crinitus basidiocarp pileus and stipe chemical composition}

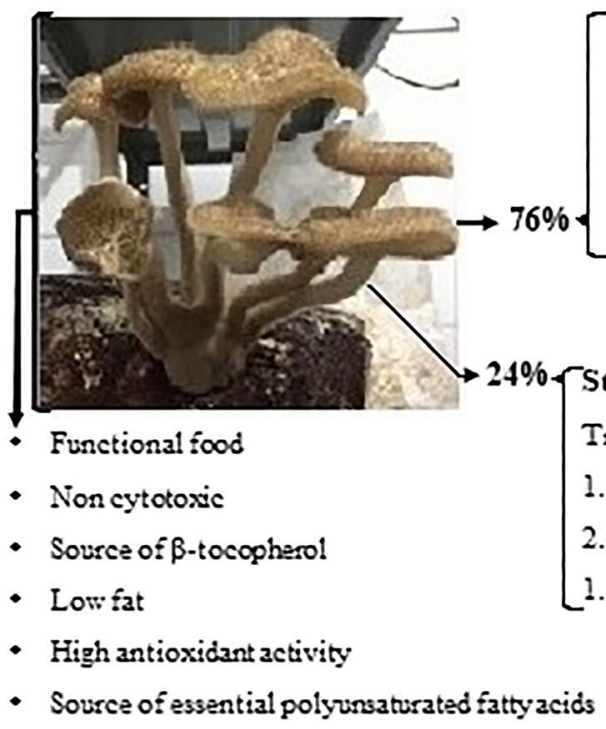

Pileus

1.5 -fold mose protein

2.2-fold more mannitol

Trehalose source $(3.1 \mathrm{~g} / 100 \mathrm{~g})$

7.0-fold mose organic zcids

$\$ 3 \%$ malic acid

$17 \%$ oxalic acid

Trehalose source $(3.2 \mathrm{~g} / 100 \mathrm{~g})$

1.1-fold more total soluble sugars

2.6-fold more sucrose

1.5 -fold more phenoliczeids

$95 \%$ p-hydroxybenzosc actd

$5 \%$ cinnamic acid

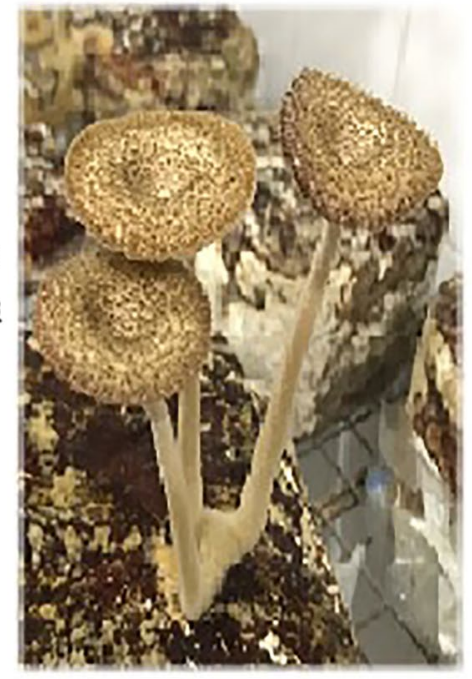

Keywords Basidiocarp $\cdot \beta$-Tocopherol $\cdot$ Linoleic acid $\cdot$ Malic acid $\cdot p$-Hydroxybenzoic acid $\cdot$ Trehalose

\section{Introduction}

Mushrooms are prized for their taste, nutritional value, and bioactive compounds used for health and well-being [1-5] but just some of them are cultivated in industrial scale worldwide such as Pleurotus, Lentinula, Auricularia, Agaricus, Flammulina, Coprinus, Agrocybe, and Volvariella genera [6-13].

Lentinus crinitus (L.) Fr. (Basidiomycota) is a saprotrophic wild fungus growing on decaying tree trunks [14, 15] with a pantropical and neotropical distribution [16]. It is an important part of a regular diet of ethnic groups from the Amazon such as the Yanomami (Yanomamö) Indians, and it is boiled in water or roasted in banana leaves before eating [14]. This author also reported that the Yanomami Indians from Tototobi village have two words for eating, one for meat and one for other foods. The word for meat consumption is also applied to mushrooms, and they are supposed to consider this protein source equivalent to meat and eat it, despite being tough and leathery.

Lentinus crinitus has broad ligninolytic activity, producing several enzymes such as laccases and proteases [17-20]; high antioxidant potential [21]; having been reported as a producer of antimicrobial [22, 23], antibiotic [15], and antitumoral [24, 25] compounds. In addition, it is simultaneously able to bioaccumulate lithium in the mycelial biomass, which makes it an option as a functional food $[26,27]$. L. crinitus also has been used for degradation and discoloration of textile dyes [28, 29] and bioremediation of contaminated soils with chemicals such as organochlorines [30] and dichlorophenoxyacetic acid $(2,4-\mathrm{D})$ [31].

Mushroom production can be a low environmental impact and profitable activity, mainly for Brazilian rural farmers. To promote mushroom consumption and production of $L$. crinitus, it is necessary to evaluate its biological and cytotoxic activities. There are few studies on $L$. crinitus chemical composition [23, 32, 33] and no reports were found on the cytotoxicity activity of this mushroom. Moreover, L. crinitus stipe has a higher toughness than the pileus, and can be considered a by-product of mushroom production. Both pileus and stipe could have different chemical compositions [34] and, therefore, they can be used for different purposes. Though, no reports comparing the chemical composition and biological activity of $L$. crinitus pileus and stipe have been found.

Despite L. crinitus biological activities, biotechnological applications, and ethnomycological studies, no reports on its basidiocarp chemical composition and cytotoxic activity have been found. Thus, the objective of this study was to determine and evaluate the chemical composition and antioxidant and cytotoxic activities of $L$. crinitus 
basidiocarp, cultivated in agro-industrial residues, comparing the results obtained for the pileus and stipe.

\section{Materials and methods}

\section{Biological material}

Lentinus crinitus (L.) Fr. U9-1 strain from the culture collection of the Laboratory of Molecular Biology of the Paranaense University, GenBank accession numbers MG211674, was used. The strain was registered under the code A04E776 in the National System of Genetic Patrimony Management and Associated Traditional Knowledge (SisGen, its acronym in Portuguese). The cryopreserved fungus at -86 ${ }^{\circ} \mathrm{C}$, according to Linde et al. [35], Zaghi Jr et al. [36] and Tanaka et al. [19], was transferred to malt extract agar medium $\left(39 \mathrm{~g} / \mathrm{L}\right.$; MEA) and kept at $28{ }^{\circ} \mathrm{C}$ in the dark to recover mycelial vigor. Mycelia from the colony edge with homogenous branching and without sectoring were used as inoculum. For mushroom (basidiocarp) production, the cultivation substrate consisted of sugarcane bagasse and rice husk (1:1), according to Colauto and Eira [37] and Machado et al. [32], and substrate carbon-to-nitrogen $(\mathrm{C} / \mathrm{N})$ was 48 . Each substrate was kept at $28{ }^{\circ} \mathrm{C}$ until complete colonization (30 days) without room ventilation, the top part of the cultivation bag was opened, the room temperature reduced to $18{ }^{\circ} \mathrm{C}$ for $24 \mathrm{~h}$ (thermal shock), and ventilation was started to reduce carbon dioxide but relative humidity was kept at $80 \%$ throughout cultivation period [37]. Basidiocarps were harvested daily when the pileus border was flat, indicating the end of basidiocarp growth and the beginning of basidiocarp senescence. The basidiocarps $(n=512)$ were dehydrated in an oven with air circulation at $60{ }^{\circ} \mathrm{C}$ until constant mass. Basidiocarp pileus and stipe were separated, ground in an industrial blender, homogenized, and kept in separate Falcon tubes at $-20^{\circ} \mathrm{C}$.

\section{Biological material and production and processing of basidiocarps}

\section{Nutritional value of basidiocarp pileus and stipe}

The proximate composition (protein, fat, ash, and carbohydrates content) of the samples was determined according to standard procedures [38]. The crude protein content $(N \times 4.38)$ of the samples was estimated by the macroKjeldahl method; crude fat was determined by extracting a known mass of powdered sample with petroleum ether, using a Soxhlet apparatus; ash content was determined by incineration at $600 \pm 15^{\circ} \mathrm{C}$. Total carbohydrates were calculated by difference [total carbohydrates $(g / 100 \mathrm{~g}$; dry basis $\left.)=100-\left(g_{\text {protein }}+g_{\text {fat }}+g_{\text {ash }}\right)\right]$. The energy was calculated according to Regulation (EC) number 1169/2011 of the European Parliament and of the Council, of 25 October 2011, on the Provision of Food Information to Consumers [39], as: Energy [(kcal/100 g; dry basis $)=4 \times\left(g_{\text {protein }}+\right.$ $\left.\left.g_{\text {carbohydrates }}\right)+9 \times\left(g_{\text {fat }}\right)\right]$.

\section{Hydrophilic compounds}

Soluble sugars The soluble sugars present in $L$. crinitus basidiocarp pileus and stipe were analyzed by high-performance liquid chromatography (HPLC) using a refraction index (RI) detector. This methodology was conducted according to a previously described methodology [40]. The results were expressed in $\mathrm{g}$ per $100 \mathrm{~g}$ (dry basis).

Organic acids The organic acid profile of the studied samples was determined following a procedure previously optimized and described by Barros et al. [41]. The analysis was performed by ultra-fast liquid chromatography (UFLC) coupled to a photodiode array detector (PDA) following the previously referred procedure. The organic acids were quantified by comparison of the peak area recorded at $215 \mathrm{~nm}$ ( $245 \mathrm{~nm}$ for ascorbic acid) with calibration curves obtained from commercial standards of each compound. The results were expressed in mg per $100 \mathrm{~g}$ (dry basis).

\section{Other organic acids}

Phenolic acids and related compounds The phenolic acid determination was performed by an UPLC system coupled to a PDA and a mass detector (LC-DAD-ESI/MSn), according to a previously described procedure [42]. The phenolic compounds were identified by comparing their retention times, $\mathrm{UV}-\mathrm{Vis}$ and mass spectra with those obtained with standard compounds, when available. Otherwise, compounds were tentatively identified, comparing the obtained information with available data reported in the literature. For quantitative analysis, a calibration curve for each available phenolic standard was constructed based on the UV-Vis signal. For the identified phenolic compounds to which a commercial standard was not available, the quantification was performed through the calibration curve of another compound from the same phenolic group [42]. The results were expressed as $\mu \mathrm{g}$ per $100 \mathrm{~g}$ (dry basis).

\section{Lipophilic compounds}

Fatty acids The fatty acids profile of the samples was determined by gas-liquid chromatography with flame ionization detection (GC-FID)/capillary column as described previously by Reis et al. [43]. The identification of the different fatty acids was made by comparison of the relative retention times of FAME (fatty acid methyl esters) peaks from 
samples with standards. The results were expressed in the relative percentage of each fatty acid.

Tocopherols The methodology used to determine the tocopherol composition was according to Heleno et al. [44]. The analysis was performed using the same HPLC system described for soluble sugar, but coupled to a fluorescence detector. The tocopherol identification was performed by chromatographic comparisons with authentic standards and the quantification was based on the fluorescence signal response of each standard. The results were expressed in $\mu \mathrm{g}$ per $100 \mathrm{~g}$ (dry basis).

\section{Bioactivity evaluation of basidiocarp pileus and stipe}

\section{Extract preparation}

For each dried sample of basidiocarp pileus or stipe, $1 \mathrm{~g}$ (as described in "Biological material") was extracted with $30-\mathrm{mL}$ ethanol under magnetic stirring for $1 \mathrm{~h}$ at room temperature $(n=3)$. Then, each residue was re-extracted maintaining the same operational conditions. The extracts were mixed and evaporated at $40{ }^{\circ} \mathrm{C}$ in a rotary evaporator (Büchi R-210, Flawil, Switzerland) to remove alcohol and be lyophilized. Each lyophilized extract was re-dissolved at $8 \mathrm{mg} / \mathrm{mL}$ in autoclaved distilled water to assess the cytotoxic activity. Subsequently, each solution was diluted successively to obtain the concentration necessary to perform the experimental study.

\section{Cytotoxic activity of basidiocarp pileus and stipe in human tumor cell lines and non-tumor cells}

Four human tumor cell lines were used, namely HeLa (cervical carcinoma), HepG2 (hepatocellular carcinoma), MCF7 (breast adenocarcinoma), and NCI-H460 (non-small cell lung cancer). Cells were routinely maintained as adherent cell cultures. Cells were treated for $48 \mathrm{~h}$ with the diluted extract solutions [45]. The adherent cells were fixed by adding cold $10 \%$ trichloroacetic acid (TCA, $100 \mathrm{~mL}$ ) and incubated for $60 \mathrm{~min}$ at $4{ }^{\circ} \mathrm{C}$. Plates were then washed with deionized water and dried; sulforhodamine B solution $(0.1 \%$ in $1 \%$ acetic acid, $100 \mathrm{~mL}$ ) was then added to each plate well and incubated for $30 \mathrm{~min}$ at room temperature. Unbound SRB was removed by washing with $1 \%$ acetic acid. Plates were air-dried, the bound SRB was solubilized with $10 \mathrm{mM}$ Tris $(200 \mathrm{ml}, \mathrm{pH}$ 7.4) and the absorbance was measured at $540 \mathrm{~nm}$. The results were expressed as $\mathrm{GI}_{50}$ values (sample concentration that inhibited $50 \%$ of the net cell growth). Ellipticine was used as a positive control.

For the possible hepatotoxicity evaluation, a culture cell obtained from porcine liver, designed as PLP2, was used [46].
The same procedure described above for the SRB assay was performed for the growth inhibition. The results were also expressed as $\mathrm{GI}_{50}$ values.

\section{Antioxidant activity of basidiocarp pileus and stipe}

To obtain the methanolic extract, $1 \mathrm{~g}$ basidiocarp pileus or stipe (dry basis) was homogenized with $10-\mathrm{mL}$ methyl alcohol in Falcon tubes. The mixture was kept at $60^{\circ} \mathrm{C}$ for $45 \mathrm{~min}$, and centrifuged at $6000 \mathrm{~g}$ at $5{ }^{\circ} \mathrm{C}$ for $10 \mathrm{~min}$. The supernatant was considered the crude extract. The total antioxidant capacity of $L$. crinitus extracts was evaluated by 2,2-diphenyl-1-picrylhydrazyl $\left(\mathrm{DPPH}^{\circ}\right)$ free radical sequestration method. The inhibitory concentration to reduce $50 \%$ of free radicals $\left(\mathrm{IC}_{50}\right)$ in a sample was determined from a correlation among absorbance and sample concentrations. All assays were performed in triplicate $[47,48]$.

The antioxidant activity was also evaluated by the ferric reducing antioxidant power (FRAP) method. The antioxidant activity of each reaction was calculated against a standard ferrous sulfate curve $(2000 \mu \mathrm{M})$ and as positive control $800 \mu \mathrm{M}$ trolox (6-hydroxy-2,5,7,8-tetramethylchroman-2-carboxylic acid) was used [49]. All assays were performed in triplicate.

The antioxidant activity of basidiocarp pileus or stipe extract was also evaluated by co-oxidation of $\beta$-carotene/linoleic acid (BCLA) method, according to Mattos et al. [50]. The reaction was maintained at $40{ }^{\circ} \mathrm{C}$ for $120 \mathrm{~min}$ and the absorbance was measured at $470 \mathrm{~nm}$ (SpectraMax Plus ${ }^{384}$ Microplate Reader), every $5 \mathrm{~min}$, from 0 to $120 \mathrm{~min}$. Trolox $(100 \mu \mathrm{g} / \mathrm{mL})$ was used as a positive control. The results were expressed as the absorbance reduction along the reaction time. The $\beta$-carotene bleaching rate was calculated according to the following equation:

$R=\ln (a / b) / t$

Table 1 Macronutrient composition and energetic value of Lentinus crinitus basidiocarp pileus and stipe

\begin{tabular}{lccl}
\hline Parameter & \multicolumn{2}{l}{ Basidiocarp } & \multirow{2}{*}{$p$ value } \\
\cline { 2 - 3 } & Pileus & Stipe & \\
\hline Ash $(\mathrm{g} / 100 \mathrm{~g})$ & $4.29 \pm 0.07$ & $2.66 \pm 0.02$ & $<0.001$ \\
Proteins $(\mathrm{g} / 100 \mathrm{~g})$ & $14.4 \pm 0.3$ & $9.5 \pm 0.1$ & $<0.001$ \\
Fat $(\mathrm{g} / 100 \mathrm{~g})$ & $0.52 \pm 0.03$ & $0.55 \pm 0.02$ & 0.02 \\
Carbohydrates $(\mathrm{g} / 100 \mathrm{~g})$ & $80.8 \pm 0.3$ & $87.3 \pm 0.2$ & $<0.001$ \\
Energy $(\mathrm{kcal} / 100 \mathrm{~g})$ & $385.5 \pm 0.4$ & $392.15 \pm 0.03$ & $<0.001$ \\
\hline
\end{tabular}

Values expressed as arithmetic mean \pm standard deviation (dry basis) expressed as $\mathrm{g} / 100 \mathrm{~g}$, except for energy expressed as kcal/100 $\mathrm{g}$

$p$ value indicates significant differences by the Student's $t$ test $(p \leq 0.05 ; n=9)$ 
Table 2 Chemical composition in the hydrophilic extract (sugars, organic acids, and phenolic acids) of Lentinus crinitus basidiocarp pileus and stipe

\begin{tabular}{llll}
\hline Compound & \multicolumn{2}{l}{ Basidiocarp } & \multirow{2}{*}{$p$ value } \\
\cline { 2 - 3 } & Pileus & Stipe & \\
\hline Sugars $(\mathrm{g} / 100 \mathrm{~g})$ & & & \\
Mannitol & $0.18 \pm 0.001$ & $0.08 \pm 0.02$ & $<0.001$ \\
Sucrose & $0.260 \pm 0.007$ & $0.69 \pm 0.02$ & $<0.001$ \\
Trehalose & $3.13 \pm 0.07$ & $3.2 \pm 0.3$ & 0.528 \\
Total soluble sugars & $3.57 \pm 0.06$ & $3.97 \pm 0.50$ & 0.039 \\
Organic acids $(\mathrm{mg} / 100)$ & & & \\
Oxalic acid & $165 \pm 1$ & $\operatorname{tr}$ & - \\
Malic Acid & $801 \pm 12$ & $137 \pm 1$ & $<0.001$ \\
Fumaric acid & $0.0425 \pm 0.0006$ & $\mathrm{tr}$ & - \\
Total organic acids & $966 \pm 15$ & $137 \pm 1$ & $<0.001$ \\
Phenolic acids $(\mu \mathrm{g} / 100 \mathrm{~g})$ & & & \\
$p$-Hydroxybenzoic acid & $537 \pm 4$ & $791 \pm 3$ & $<0.001$ \\
Cinnamic acid & $81.2 \pm 0.2$ & $38.2 \pm 0.5$ & $<0.001$ \\
Total phenolic acids & $537 \pm 4$ & $791 \pm 3$ & $<0.001$ \\
\hline
\end{tabular}

Values expressed as arithmetic mean \pm standard deviation (dry basis) tr trace

$p$ value indicates significant differences by the Student's $t$ test $(p \leq 0.05 ; n=9)$

where $\mathrm{R}$ is the bleaching rate of $\beta$-carotene in the mixture; $\ln$ is the natural log; $\mathrm{a}$ is the absorbance in zero time; $\mathrm{b}$ is the absorbance in t time $(t=0,5,10, \ldots 120 \mathrm{~min})$.

The antioxidant activity was calculated according to the percentage of inhibition in relation to the control, using the following equation:

Antioxidant activity $=\left[\left(R_{\text {control }}-R_{\text {sample }}\right) / R_{\text {control }}\right] \times 100$

where $R_{\text {control }}$ and $R_{\text {sample }}$ were the bleaching rates of $\beta$-carotene in the mixture without the antioxidant $\left(R_{\text {control }}\right)$ and with basidiocarp pileus or stipe extract $\left(R_{\text {sample }}\right)$ [51].

\section{Statistical analysis}

Three dried samples of L. crinitus pileus or stipe (as described in "Biological material") were used and all assays were carried out in triplicate $(n=9)$. Results were expressed as arithmetic mean values and standard deviation. The results of each parameter were compared by means of the Student's $t$ test to determine the significant difference between samples $(p \leq 0.05)$. This analysis was carried out using SPSS software program (IBM SPSS software, Armonk, NY, USA). Antioxidant activity statistical analysis was determined by Tukey's test $(p \leq 0.05)$.

\section{Results}

The whole basidiocarp has an average natural pileus:stipe proportion of 76:24 (mass:mass) based on the assay cultivation conditions. The basidiocarp is leathery (tough) when harvested at the senescence phase, as found in our study, but it is tender when harvested at the beginning of the fructification (young phase). The pileus that is tenderer than the stipe had 1.5- and 1.6-fold higher proteins and ashes than the stipe, respectively (Table 1). The pileus also had sevenfold more organic acids than the stipe and the major ones were malic and oxalic acids (Table 2). The pileus had 5.8-fold more malic acid than the stipe and more oxalic acid than that stipe, which has only traces (Table 2). Malic acid represents 83 and $100 \%$ of total organic acids in the pileus and the stipe, respectively (Table 2 ).

The stipe presented a higher content of carbohydrates and energy than the pileus, but fat content was the same (Table 1). The stipe also had 1.1-fold higher total soluble sugars than the pileus, mainly sucrose that was 2.6-fold higher than the pileus, but mannitol was 2.2-fold lower than the pileus (Table 2). Trehalose content was the same for the pileus and the stipe, and it represents 88 and $82 \%$ of the total soluble sugar content, respectively (Table 2). The stipe had also 1.5-fold higher phenolic acids than the pileus and the major acids were $p$-hydroxybenzoic and cinnamic acids (Table 2). The stipe had 1.5-fold more $p$-hydroxybenzoic acid than the pileus, but the cinnamic acid was 2.1-fold higher in the pileus than the stipe (Table 2). $p$-Hydroxybenzoic acid represents almost $100 \%$ of the phenolic acids in the pileus and the stipe (Table 2).

The lipid fractions of basidiocarp pileus and stipe presented similar compositions with 21 fatty acids identified by GC analyses (Table 3 ). Polyunsaturated fatty acids were the predominant class $(\sim 63 \%)$, followed by saturated fatty acids $(\sim 23 \%)$, and monounsaturated fatty acids $(\sim 14 \%)$ (Table 3 ). The amount of each lipophilic acid was similar in the pileus and the stipe (Table 3). The major compounds in the pileus and the stipe were $\mathrm{C} 18$ series such as the linoleic $(\sim 60 \%)$ and oleic $(\sim 13 \%)$ acids and C16 series such as the palmitic $(\sim 13 \%)$ acid (Table 3$)$. The basidiocarp pileus and stipe presented important unsaturated fatty acids such as arachidic, eicosenoic, cis-11,14-eicosadienoic, cis-11,14,17eicosatrienoic, and heneicosanoic acids $(\sim 0.2 \%$ each) from the $\mathrm{C} 20$ series, and behenic $(\sim 2.5 \%)$ acid from the $\mathrm{C} 22: 0$ series, which are important essential fatty acids even in small amounts. In addition, basidiocarp pileus had $\beta$-tocopherol 1.2-fold higher than the stipe (Table 3).

The basidiocarp pileus and stipe extracts presented low antioxidant activity by DPPH $\bullet$ method of $\sim 6000$ and 12,000-fold lower than the control quercetin (Table 4). However, the pileus and stipe extracts had high antioxidant 
Table 3 Chemical composition in the lipophilic extract (fatty acids, relative percentage, and tocopherols) of Lentinus crinitus basidiocarp pileus and stipe
Table 4 Antioxidant activity from extract of Lentinus crinitus basidiocarp pileus and stipe by free radical reduction method 2,2-diphenyl-1-picrylhydrazyl (DPPH•) and ferric reducing antioxidant power (FRAP)

\begin{tabular}{|c|c|c|c|}
\hline \multirow[t]{2}{*}{ Compound } & \multicolumn{2}{|l|}{ Basidiocarp } & \multirow[t]{2}{*}{$p$ value } \\
\hline & Pileus (\%) & Stipe $(\%)$ & \\
\hline Caproic acid (C6:0) & $0.264 \pm 0.001$ & $0.317 \pm 0.001$ & $<0.001$ \\
\hline Caprylic acid (C8:0) & $0.317 \pm 0.005$ & $0.189 \pm 0.007$ & $<0.001$ \\
\hline Capric acid (C10:0) & $0.66 \pm 0.02$ & $0.1229 \pm 0.0009$ & $<0.001$ \\
\hline Lauric acid (C12:0) & $0.546 \pm 0.004$ & $0.463 \pm 0.003$ & $<0.001$ \\
\hline Myristic acid (C14:0) & $1.23 \pm 0.02$ & $1.33 \pm 0.01$ & $<0.001$ \\
\hline Pentadecanoic acid (C15:0) & $0.919 \pm 0.008$ & $1.77 \pm 0.03$ & $<0.001$ \\
\hline Palmitic acid (C16:0) & $13.40 \pm 0.03$ & $12.80 \pm 0.07$ & $<0.001$ \\
\hline Palmitoleic acid (C16:1) & $0.216 \pm 0.009$ & $0.360 \pm 0.002$ & $<0.001$ \\
\hline Heptadecanoic acid (C17:0) & $0.420 \pm 0.007$ & $0.77 \pm 0.01$ & $<0.001$ \\
\hline Stearic acid $(\mathrm{C} 18: 0)$ & $2.94 \pm 0.02$ & $2.23 \pm 0.01$ & $<0.001$ \\
\hline Oleic acid (C18:1n9) & $13.5 \pm 0.4$ & $12.65 \pm 0.04$ & $<0.001$ \\
\hline Linoleic acid (C18:2n6) & $59.9 \pm 0.4$ & $61.80 \pm 0.03$ & $<0.001$ \\
\hline$\alpha$-Linolenic acid (C18:3n3) & $2.04 \pm 0.03$ & $1.20 \pm 0.04$ & $<0.001$ \\
\hline Arachidic acid (C20:0) & $0.2448 \pm 0.0008$ & $0.197 \pm 0.002$ & $<0.001$ \\
\hline Eicosenoic acid (C20:1) & $0.2974 \pm 0.0005$ & $0.118 \pm 0.002$ & $<0.001$ \\
\hline cis-11,14-Eicosadienoic acid (C20:2) & $0.326 \pm 0.009$ & $0.28 \pm 0.01$ & $<0.001$ \\
\hline $\begin{array}{l}\text { cis-11,14,17-Eicosatrienoic acid and heneicosanoic acid } \\
(\mathrm{C} 20: 3 \mathrm{n} 3+\mathrm{C} 21: 0)\end{array}$ & $0.271 \pm 0.004$ & $0.51 \pm 0.02$ & $<0.001$ \\
\hline Behenic acid $(\mathrm{C} 22: 0)$ & $2.31 \pm 0.05$ & $2.452 \pm 0.001$ & $<0.001$ \\
\hline Erucic acid (C22:1n9) & $0.053 \pm 0.002$ & $0.058 \pm 0.002$ & $<0.001$ \\
\hline Lignoceric acid (C24:0) & nd & $0.393 \pm 0.006$ & - \\
\hline Total saturated fatty acids ( $\%$ total fatty acids) & $23.23 \pm 0.04$ & $23.0 \pm 0.1$ & 0.001 \\
\hline Total monounsaturated fatty acids ( $\%$ total fatty acids) & $14.3 \pm 0.3$ & $13.18 \pm 0.04$ & $<0.001$ \\
\hline Total polyunsaturated fatty acids ( $\%$ total fatty acids) & $62.5 \pm 0.4$ & $63.74 \pm 0.07$ & $<0.001$ \\
\hline \multicolumn{4}{|l|}{ Tocopherols $(\mu \mathrm{g} / 100 \mathrm{~g})$} \\
\hline$\beta$-Tocopherol & $491 \pm 4$ & $394 \pm 3$ & $<0.001$ \\
\hline
\end{tabular}

Values expressed as arithmetic mean \pm standard deviation (dry basis)

nd not detected

$p$ value indicates significant differences by the Student's $t$ test $(p \leq 0.05 ; n=9)$

\begin{tabular}{lllll}
\hline Parameter & Quercetin & Trolox & \multicolumn{2}{l}{ Basidiocarp } \\
\cline { 4 - 4 } & & & Pileus & Stipe \\
\hline $\begin{array}{l}\mathrm{DPPH} \bullet \\
\left(\mathrm{IC}_{50} \text { in } \mathrm{mg} / \mathrm{mL}\right)\end{array}$ & $0.02 \pm 0.10 \mathrm{a}$ & na & $99 \pm 2 \mathrm{~b}$ & $197 \pm 4 \mathrm{c}$ \\
$\begin{array}{l}\text { FRAP } \\
(\mu \mathrm{mol} \mathrm{Fe}\end{array}$ & na $/ \mathrm{g}$ of sample $)$ & $10.5 \pm 0.9 \mathrm{c}$ & $35.4 \pm 0.1 \mathrm{a}$ & $26.1 \pm 0.1 \mathrm{~b}$ \\
\hline
\end{tabular}

Values expressed as arithmetic mean \pm standard deviation (dry basis). Different letters in the same row indicate significant differences by the Tukey test $(p \leq 0.05 ; n=3)$

$n a$ not applicable, $I C_{50}$ half maximal inhibitory concentration activity by FRAP method of 3.4- and 2.5 -fold higher, respectively, than the control trolox (Table 4). The pileus and stipe extracts at $100 \mathrm{mg} / \mathrm{mL}$ protected 56 and $42 \%$ of the $\beta$-carotene against oxidation, respectively. These values are equivalent to 62 and $47 \%$ of trolox protection activity (control), respectively (Fig. 1). The antioxidant activity of the basidiocarp pileus and stipe by FRAP, a polar aqueous method, and BCLA, a nonpolar method, are in agreement with the phenolic and the organic polar acids, and the nonpolar tocopherol, natural antioxidants found in L. crinitus of our study (Table 4 and Fig. 1).

The basidiocarp pileus and stipe extracts were not effective to inhibit the growth of tumor and non-tumor cells at a concentration higher than $300 \mu \mathrm{g} / \mathrm{mL}$ against HepG2 and 


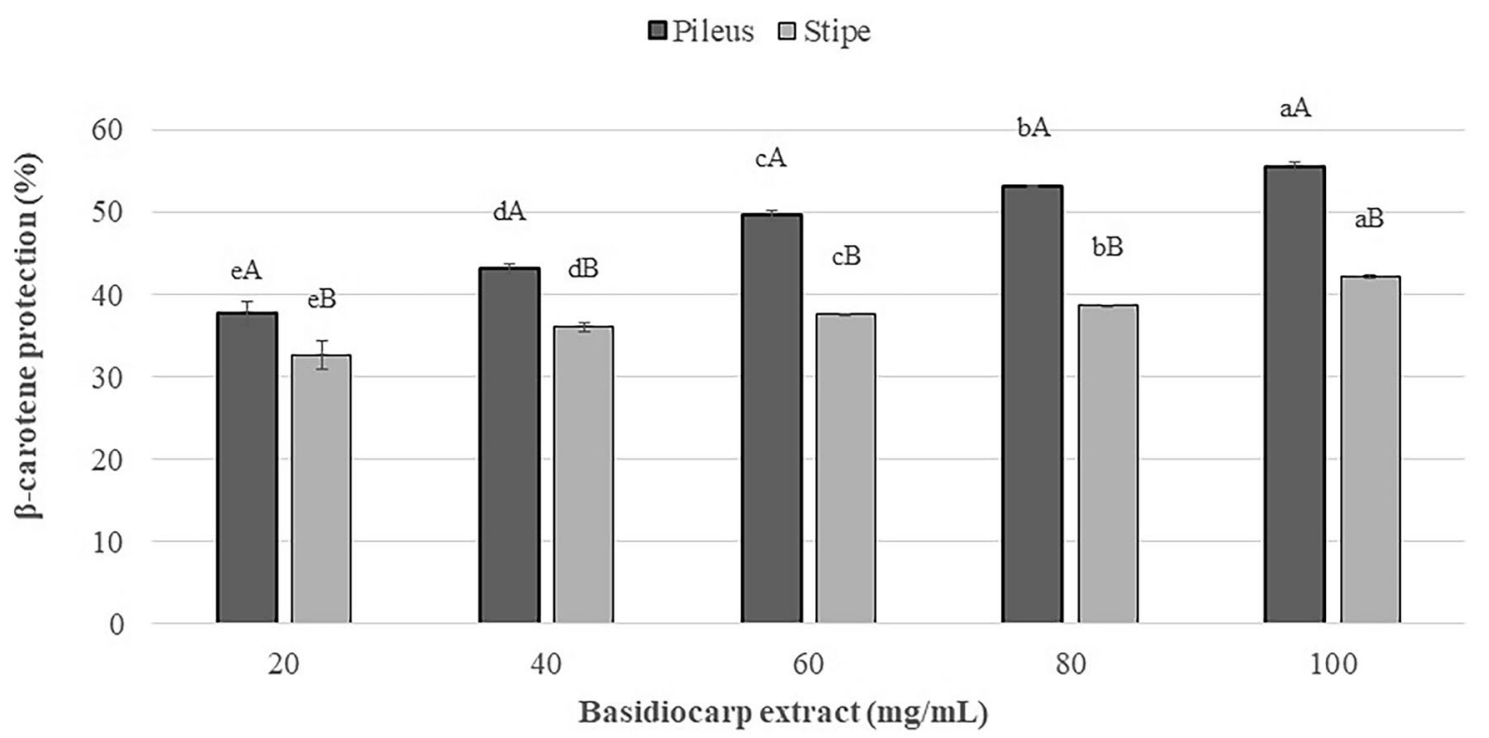

Fig. 1 Antioxidant activity of the extract of Lentinus crinitus basidiocarp pileus and stipe by the cooxidation of $\beta$-carotene/linoleic acid (BCLA) method. Values expressed as arithmetic mean \pm standard deviation (dry basis). Different upper-case letters between basidiocarp pileus and stipe, at same basidiocarp extract concentration, and

Table 5 Cytotoxic activity of the methanolic extracts of Lentinus crinitus basidiocarp pileus and stipe and positive control ellipticine against human tumor cell lines and non-tumor cells

\begin{tabular}{lllll}
\hline Cell line & \multicolumn{2}{l}{ Basidiocarp } & $p$ value & $\begin{array}{l}\text { Ellipticine } \\
\left(\mathrm{GI}_{50} \mu \mathrm{g} /\right.\end{array}$ \\
\cline { 2 - 3 } & $\begin{array}{l}\text { Pileus } \\
(\mathrm{GI} \\
\mathrm{mL})\end{array}$ & $\begin{array}{l}\text { Stipe }\left(\mathrm{GI}_{50} \mu \mathrm{g} /\right. \\
\mathrm{mL})\end{array}$ & & \\
& & & & \\
\hline Tumor cell & & & & \\
HepG2 & $303 \pm 6$ & $336.3 \pm 0.5$ & $<0.001$ & $3.2 \pm 0.5$ \\
MCF7 & $>400$ & $>400$ & - & $0.91 \pm 0.04$ \\
NCI-H460 & $>400$ & $>400$ & - & $1.42 \pm 0.01$ \\
HeLa & $>400$ & $>400$ & - & $1.1 \pm 0.2$ \\
Non-tumor cell & & & & \\
PLP2 & $>400$ & $>400$ & - & $2.06 \pm 0.03$ \\
\hline
\end{tabular}

Values expressed as arithmetic mean \pm standard deviation (dry basis). $\mathrm{GI}_{50}=$ extract concentration corresponding to $50 \%$ growth inhibition activity

MCF7 breast adenocarcinoma, NCI-H46O lung carcinoma, HeLa cervical carcinoma, HepG2 hepato cellular carcinoma

$p$ value indicates significant differences by the Student's $t$ test $(p \leq 0.05 ; n=9)$

higher than $400 \mu \mathrm{g} / \mathrm{mL}$ for MCF7, NCI-H460, HeLa, and PLP2 cells compared to the control ellipticine $(3.2 \mu \mathrm{g} / \mathrm{mL})$ (Table 5). This and the $\mathrm{GI}_{50}$ values indicate that the basidiocarp pileus and stipe had no cytotoxicity activity against tumor and non-tumor cell lines. different lower-case letters among basidiocarp pileus and/or stipe, at different basidiocarp extract concentrations, indicate statistical difference by Tukey's test $(p \leq 0.05)$. Positive control trolox at $0.2 \mathrm{mg} /$ $\mathrm{mL}=89.80 \pm 4.13 \% \beta$-carotene protection

\section{Discussion}

The high protein and low fat and energy contents of edible basidiocarps are appropriated for using them in low caloric diets [52]. Basidiocarp pileus of Pleurotus ostreatus has threefold more protein content than the stipe [53-55]. Our study showed that $L$. crinitus basidiocarp pileus has 1.5 -fold higher protein content than the stipe. This value is similar to those reported for most of consumed basidiocarps [52-55, 59]. The whole basidiocarp protein content of 25 basidiomycetes (without $L$. crinitus) ranged from 13.2 to $62.8 \mathrm{~g} / 100 \mathrm{~g}$ [56], and for Lentinus strigosus from 18.0 to $21.6 \mathrm{~g} / 100 \mathrm{~g}$ [57]. For L. crinitus, protein content of $9.8 \mathrm{~g} / 100 \mathrm{~g}$ (value converted from 6.25 to 4.38 factor; original value was $14.0 \mathrm{~g} / 100 \mathrm{~g}$ ) was reported [33], from 10.5 to $14.4 \mathrm{~g} / 100 \mathrm{~g}$ [58], and from 20.0 to $27.0 \mathrm{~g} / 100 \mathrm{~g}$ [32]. Our results showed the protein content was $13.3 \mathrm{~g} / 100 \mathrm{~g}(14.5 \mathrm{~g} / 100 \mathrm{~g}$ for the pileus and $9.5 \mathrm{~g} / 100 \mathrm{~g}$ for the stipe), considering 76:24 (mass:mass) proportion that could vary according to carbon dioxide level in the cultivation room. It indicates that the protein content in edible basidiocarps varies, but our results are like those found in the literature for $L$. crinitus. However, it is below the range reported by Chang and Miles [59] that is from 19 to $35 \mathrm{~g} / 100 \mathrm{~g}$ for edible basidiocarps and some other foods such as soybean $(39.1 \mathrm{~g} / 100 \mathrm{~g})$ and in milk $(25.2 \mathrm{~g} / 100 \mathrm{~g})$, but higher than rice $(7.3 \mathrm{~g} / 100 \mathrm{~g})$ and equivalent to wheat $(13.2 \mathrm{~g} / 100 \mathrm{~g})$. Nevertheless, the protein content reported for basidiocarps must be compared with some caution because it may vary due to lack of moist 
sample control and information of the conversion factor, which should be 4.38 instead of 6.25 (generally used for other foods), mainly because basidiocarps have high nonprotein nitrogen content [56, 59].

Our study showed that trehalose represents more than $80 \%$ of the total soluble sugars in the basidiocarp with similar amounts in the pileus and the stipe. Trehalose is the main carbohydrate in fungus, mainly because the glucose by active transport is converted to trehalose [59], and according to Kalač [56], basidiocarps have an average of $3.92 \mathrm{~g} / 100 \mathrm{~g}$, which is a close value found in our study for L. crinitus $(3.2 \mathrm{~g} / 100 \mathrm{~g})$. Trehalose migrates from mycelia to basidiocarps, and protects the cells against stresses such as desiccation, temperature, and oxygen pressures $[60,61]$. This protection mechanism seems to be related to malondialdehyde inhibition, a free radical naturally produced by lipid peroxidation with mutagenic and carcinogenic activities, and it could explain the capacity of $L$. crinitus enzymatic production [19] and mycelial biomass growth [62] under extreme conditions of temperature and $\mathrm{pH}$.

Species belonging to the genus Pleurotus contain carbohydrates ranging from 47 to $82 \mathrm{~g} / 100 \mathrm{~g}$ whereas Agaricus bisporus has $60 \mathrm{~g} / 100 \mathrm{~g}$; these water-soluble polysaccharides have been reported to inhibit tumors [59]. Thus, the high carbohydrate $(87 \mathrm{~g} / 100 \mathrm{~g})$ content, mainly trehalose $(3.2 \mathrm{~g} / 100 \mathrm{~g})$ from L. crinitus of our study, has several applications such as functional food and cosmetic and therapeutic applications [63-65]. Trehalose has been obtained in relatively small amounts by extraction from natural sources, chemical synthesis, microbial fermentation, and enzymatic conversion from maltose, but with low yield even using genetic engineering techniques [64, 66, 67]. According to Martirosyan and Singh [68], functional foods are natural or processed foods that contain known or unknown biologically active compounds at non-toxic amounts, and that provide a health benefit for the prevention, management, or treatment of a disease. L. crinitus basidiocarp, which is already regularly consumed by the Yanomami Indians, can be a source of trehalose, as the fungus is robust and can easily grow in several lignocellulolytic substrates [58].

The fat content of commercial basidiocarps ranges from 0.6 to $3.1 \mathrm{~g} / 100 \mathrm{~g}$ (A. bisporus, Auricularia spp., Flammulina velutipes, Lentinula edodes, Pholiota nameko, Pleurotus spp., Tremella fuciformis, and Volvariella volvacea) [59] and of wild basidiocarps from 0.4 to $3.8 \mathrm{~g} / 100 \mathrm{~g}$ (Cortinarius glaucopus, Fistulina hepatica, Hygrophoropsis aurantiaca, Hypholoma capnoides, Laccaria laccata, Lactarius salmonicolor, Lepista inversa, Russula delica, Suillus mediterraneensis, and Tricholoma imbricatum) [69]. In our study, L. crinitus basidiocarp showed 0.52 and $0.55 \mathrm{~g} / 100 \mathrm{~g}$ fat content for the pileus and the stipe, respectively. Silva Neto et al. [33] reported $1.5 \mathrm{~g} / 100 \mathrm{~g}$ of fat content for $L$. crinitus. This indicates that $L$. crinitus basidiocarp is an excellent alternative for low calorie diets. According to Chang and Miles [59], the energy value of the main cultivated basidiocarps ranged from 261 to $392 \mathrm{kcal} / 100 \mathrm{~g}$, and L. crinitus basidiocarp, in our study, had $385 \mathrm{kcal} / 100 \mathrm{~g}$ in the pileus and $392 \mathrm{kcal} / 100 \mathrm{~g}$ in the stipe, which is similar to the main commercial basidiocarps. In addition to the reduced fat and caloric content, the fatty acids of $L$. crinitus basidiocarp in our study had a high nutritional value since the unsaturated fatty acid amount is threefold higher than the saturated ones. The linoleic acid $(\omega-6)$ represents more than $60 \%$ fatty acids in L. crinitus basidiocarp in our study, and this polyunsaturated essential fatty acid is one of two essential ones to human diet. The linoleic acid represents $28-76 \%$ of the total lipids in commercial basidiocarps, and has been identified as the main substance with antimutagenic activity in Agaricus blazei and Grifola frondosa [59]. In the cell metabolism, the linoleic acid is the precursor of the arachidonic acid that promotes the production of inflammation mediators such as eicosanoids, prostaglandins, thromboxanes, and leukotrienes [70]. Thus, L. crinitus basidiocarp is associated with a healthy diet due to the low caloric value and a high polyunsaturated fatty acid content.

The hydrophilic fraction of $L$. crinitus basidiocarp, specifically organic acids, had malic $(801 \mathrm{mg} / 100 \mathrm{~g}$ in the pileus) and oxalic ( $165 \mathrm{mg} / 100 \mathrm{~g}$ in the pileus) acids as major compounds. Organic acids in basidiocarps are related to taste and flavor formation such as malic acid that varies from 15 to $700 \mathrm{mg} / 100 \mathrm{~g}$ for Cantharellus cibarius [71], $217 \mathrm{mg} / 100 \mathrm{~g}$ for Agaricus brasiliensis [72], and $2200 \mathrm{mg} / 100 \mathrm{~g}$ for Polyporus squamosus [73]. Oxalic acid has been reported with $76 \mathrm{mg} / 100 \mathrm{~g}$ P. squamosus [73] and $115 \mathrm{mg} / 100 \mathrm{~g}$ for A. brasiliensis [72]. It indicates that the malic and oxalic acids in our study are among the highest levels found in the literature. The main phenolic acid found in our study was $p$-hydroxybenzoic acid, found in the pileus $(537 \mu \mathrm{g} / 100 \mathrm{~g})$ and stipe $(791 \mu \mathrm{g} / 100 \mathrm{~g})$ of L. crinitus basidiocarp. The $p$-hydroxybenzoic acid content has been reported from 0 to $23.9 \mathrm{mg} / 100 \mathrm{~g}$ (average of $3.4 \mathrm{mg} / 100 \mathrm{~g}$ ) among 16 wild basidiocarps [74], and from 0.5 to $2.4 \mathrm{mg} / 100 \mathrm{~g}$ (average of $1.3 \mathrm{mg} / 100 \mathrm{~g}$ ) among eight commercial basidiocarps [75]. This indicates that the $p$-hydroxybenzoic acid in our study is among the lowest levels found in the cited literature in this paragraph. Cinnamic acid is a precursor of other complex phenolic compounds, mainly found in several plants, and with anticancer, antituberculosis, antimalarial, antifungal, antimicrobial, antiatherogenic, and antioxidant activities, and also used to alter the potency, permeability, solubility or other parameters of drugs [76]. Phenolic compounds could improve chemical stability and shelf life of foods and cosmetics as they are strong antioxidants [77]. However, the phenolic acid content of $L$. crinitus basidiocarp in our study may explain its high antioxidant activity by the FRAP method, as the phenolic acids can chelate metals or 
displace the electrical charge stabilizing free radicals [78, 79]. In addition, as far as we know, this is the first report concerning the organic and phenolic acid contents of $L$. crinitus basidiocarp pileus and stipe.

Different basidiocarp compounds are associated with antioxidant activity [80], but tocopherols and phenolic compounds are the most important studied ones, although the organic acids have been associated with the antioxidant activity of A. brasiliensis, mainly for BCLA method [72]. Our results showed that $L$. crinitus basidiocarp pileus and stipe have high antioxidant activity by the FRAP and BCLA methods and high amounts of antioxidant compounds such as malic and $p$-hydroxybenzoic acids and $\beta$-tocopherol. Reis et al. [81] reported $\beta$-tocopherol contents of 48.2 and $1.61 \mu \mathrm{g} / 100 \mathrm{~g}$, respectively, for Pleurotus eryngii and A. bisporus. In our study, $L$. crinitus pileus and stipe had $\sim$ tenfold more $\beta$-tocopherol (491.0 and $394.0 \mu \mathrm{g} / 100 \mathrm{~g}$, respectively) than cited $P$. eryngii and A. bisporus. In general, the basidiocarp antioxidant activity can be attributed to the ability to donate hydrogen, chelate metals, and its effectiveness as good scavengers of superoxide and free radicals [82]. Our results showed that $L$. crinitus pileus and stipe have 2.4- and 1.5-fold more antioxidant activities than the positive control trolox, reinforcing that this basidiocarp is a functional food.

L. crinitus basidiocarp pileus and stipe had very low cytotoxicity against HepG2 and no cytotoxicity against MCF7, NCI-H460, and HeLa tumor cell lines. Cytotoxicity activity for several cell lines was reported for the panepoxydonecompound isolated from $L$. crinitus [24, 83-87]. In addition, there were no cytotoxicity against PLP2 non-tumor cells-a mandatory cytotoxicity test [88]—showing that this basidiomycete might be used in diets as it is already done by the Amazonian Indians in Brazil [14].

\section{Conclusions}

The basidiocarp of $L$. crinitus has a pileus:stipe proportion of 76:24 (mass:mass). The pileus has high levels of protein, ash, tocopherols, and organic acids, mainly malic and oxalic acids. The stipe has a high content of carbohydrates, energy, soluble sugars, and phenolic acids, mostly $p$-hydroxybenzoic acid. Basidiocarp pileus or stipe has trehalose as the main soluble sugar and less than $1 \%$ fat being $~ 60 \%$ polyunsaturated fatty acids, mostly linoleic and oleic acids, and 13\% saturated fatty acids, mostly palmitic acid. It has high antioxidant activity by FRAP and BCLA methods, but low antioxidant activity by DPPH• method; it has no cytotoxic activity against tumor and non-tumor cells. The basidiocarp pileus and stipe of $L$. crinitus are functional foods with antioxidant activity, and sources of protein, polyunsaturated fatty acids, malic acid, $p$-hydroxybenzoic acid, trehalose, and tocopherols. The basidiocarp has no cytotoxicity, enabling its use in the food, cosmetic, and pharmaceutical industries.

Acknowledgements The authors thank Universidade Paranaense, UniCesumar, Polytechnic Institute of Bragança, Coordenação de Aperfeiçoamento de Pessoal de Nível Superior_-Brazil (CAPES)—finance code 001-, Conselho Nacional de Desenvolvimento Científico e Tecnológico $(\mathrm{CNPq})$, and Fundação Araucária for the financial support and the fellowship.

Funding This research was supported by Universidade Paranaense, UniCesumar, Polytechnic Institute of Bragança, Coordenação de Aperfeiçoamento de Pessoal de Nível Superior-Brazil (CAPES)—finance code 001-, Conselho Nacional de Desenvolvimento Científico e Tecnológico $(\mathrm{CNPq})$, and Fundação Araucária. The authors are also grateful to the Foundation for Science and Technology (FCT, Portugal) for financial support through national funds FCT/MCTES to CIMO (UIDB/00690/2020); to the national funding by FCT, P.I., through the institutional scientific employment program-contract for L. Barros contract.

\section{Declarations}

Conflict of interest The authors declare no conflict of interest.

\section{References}

1. Leal AR, Barros L, Barreira JCM et al (2013) Portuguese wild mushrooms at the "pharma-nutrition" interface: Nutritional characterization and antioxidant properties. Food Res Int 50:1-9

2. Bertéli MBD, Umeo SH, Bertéli A, Valle JS et al (2014) Mycelial antineoplastic activity of Agaricus blazei. World J Microb Biot 30:2307-2313

3. Bertéli MBD, Lopes AD, Colla IM, Linde GL et al (2016) Agaricus subrufescens: substratum nitrogen concentration and mycelial extraction method on antitumor activity. An Acad Bras Ciênc 88:2239-2246

4. Aras A, Khalid S, Jabeen S, Farooqi AA et al (2018) Regulation of cancer cell signaling pathways by mushrooms and their bioactive molecules: overview of the journey from benchtop to clinical trials. Food Chem Toxicol 119:206-214. https://doi.org/10.1016/j. fct.2018.04.038

5. Blackwell M (2011) The fungi: 1, 2, 3 .. 5.1 million species? Am J Bot 98:426-438

6. Colauto NB (2008) Temperature and $\mathrm{pH}$ conditions for mycelial growth of Agaricus brasiliensis on axenic cultivation. Semina Ciênc Agrár 29:307-312

7. Li Y (2012) Present development situation and tendency of edible mushroom industry in China. In: Proceedings of the Congress of the International Society for Mushroom Science, Beijing, pp 3-9.

8. Tanaka HS, Mantovani TRD, Santos MP, Linde GA et al (2013) Cereal grains and glycerol in Agaricus blazei cryopreservation. Biosci J 29:627-633

9. Klaus A, Kozarski M, Vunduk J, Todorovic N (2015) Biological potential of extracts of the wild edible Basidiomycete mushroom Grifola frondosa. Food Res Int 67:272-283. https://doi.org/10. 1016/j.foodres.2014.11.035

10. Colauto NB, Fermor TR, Eira AF, Linde GA et al (2016) Pseudomonas putida stimulates primordia on Agaricus bitorquis. Curr Microbiol 72:482-488

11. Gaitán-Hernández R, López-Peña D, Esqueda M, Gutiérrez A (2019) Review of bioactive molecules production, biomass, 
and basidiomata of shiitake culinary-medicinal mushrooms, Lentinus edodes (Agaricomycetes). Int J Med Mushrooms 21:841-850

12. Tanaka HS, Bertéli MBD, Cordeiro FA, Lopes AD et al (2019) Semisolid culture medium improves mycelial recovery of Agaricus subrufescens cryopreserved in cereal grains. Braz J Microbiol 50:527-532

13. Crespão LP, Rosenberger AG, Lima FS, Delgado BMB et al (2020) Sugarcane biomass colonized by Pleurotus ostreatus for red 4B dye removal: a sustainable alternative. Environ Technol $1: 1-13$

14. Prance GT (1984) The use of edible fungi by Amazonian Indians. Adv Econ Bot 1:127-139

15. Abraham WR, Abate D (1995) Chromanones from Lentinus crinitus (basidiomycetes). Z Naturforsch 50c:748-750

16. Silva GT, Gibertoni TB (2006) Aphyllophorales (Basidiomycota) em áreas urbanas da Região Metropolitana do Recife, PE, Brasil. Hoehnea 33:533-543

17. Valle JS, Vanderbergue L, Santana TT, Almeida PH et al (2014) Soccol, optimum conditions for inducing laccase production in Lentinus crinitus. Genet Mol Res 13:8544-8551

18. Almeida PH, Oliveira ACC, Souza GPN, Friedrich JC et al (2018) Decolorization of remazol brilliant blue $\mathrm{R}$ with laccase from Lentinus crinitus grown in agro-industrial by-products. An Acad Bras Cienc 90:3463-3473

19. Marim RA, Avelino KV, Linde GA, Colauto NB et al (2018) Lentinus crinitus strains respond differently to cultivation $\mathrm{pH}$ and temperature. Genet Mol Res 17:1-7

20. Santana TT, Linde GA, Colauto NB, Valle JS (2018) Metallicaromatic compounds synergistically induce Lentinus crinitus laccase production. Biocatal Agric Biotechnol 16:625-630

21. Umeo SH, Souza GPN, Rapachi PM, Garcia DM et al (2015) Screening of basidiomycetes in submerged cultivation based on antioxidant activity. Genet Mol Res 14:9907-9914. https://doi. org/10.4238/2015.August.19.25

22. Ranadive KR, Belsare MH, Deokule SS, Jagtap NV et al (2013) Glimpses of antimicrobial activity of fungi from World. JNBR 2:142-162

23. Figueiredo A, Silva ACE (2014) Activity in vitro of extracts from Pycnoporus sanguineus and Lentinus crinitus on the pathogen Fusarium sp. Acta Amaz 44:1-8

24. Erkel G, Anke T, Sterner O (1996) Inhibition of NF-kappa B activation by panepoxydone. Biochem Biophys Res Commun 226:214-221

25. Wasser S (2014) Medicinal mushroom science: current perspectives, advances, evidences, and challenges. Biomed J 37:345-356

26. Faria MGI, Valle JS, Lopes AD, Gonçalves AC et al (2018) Mycelial bioaccumulation of lithium $\left(\mathrm{Li}_{2} \mathrm{CO}_{3}\right)$ in Pleurotus ostreatus. Int J Med Mushrooms 235:538-542

27. Faria MGI, Avelino KV, Valle JS, Silva GJ (2019) Lithium bioaccumulation in Lentinus crinitus mycelial biomass as a potential functional food. Chemosphere 235:538-542

28. Niebisch CH, Malinowski AK, Schadeck R, Mitchell DA et al (2010) Decolorization and biodegradation of reactive blue 220 textile dye by Lentinus crinitus extracellular extract. J Hazard 180:316-322

29. Tavares MF, Avelino KV, Araújo NL, Marim RA et al (2020) Decolorization of azo and anthraquinone dyes by crude laccase produced by Lentinus crinitus in solid state cultivation. Braz $\mathrm{J}$ Microbiol 51:99-106

30. Machado KMG, Matheus DR, Bononi VLR (2005) Ligninolytic enzymes production and Remazol brilliant Blue $\mathrm{R}$ decolorization by tropical Brazilian basidiomycetes fungi. Braz J Microbiol 36:246-252

31. Serbent MP, Guimarães DKS, Drechsler-Santos ER, Helm CV et al (2020) Growth, enzymatic production and morphology of the white-rot fungi Lentinus crinitus (L.) Fr. upon 2,4-D herbicide exposition. Int J Environ Sci Technol 17:2995-3012

32. Machado ARG, Teixeira MFS, Kirsch LS, Campelo MCL et al (2016) Nutritional value and proteases of Lentinus citrinus produced by solid state fermentation of lignocellulosic waste from tropical region. Saudi J Biol Sci 23:621-627

33. Silva Neto CM, Pinto DS, Santos LAC, Calaca FJS (2019) Bromatological aspects of Lentinus crinitus mushroom (Basidiomycota: Polyporaceae) in agroforestry in the Cerrado. LWT 2019:1-6

34. Ferreira ICFR, Baptista P, Vilas-Boas M, Barros L (2007) Freeradical scavenging capacity and reducing power of wild edible mushrooms from northeast Portugal: individual cap and stipe activity. Food Chem 100:1511-1516

35. Linde GA, Luciani A, Lopes AD, Valle JS et al (2018) Long-term cryopreservation of basidiomycetes. Braz J Microbiol 49:220 231. https://doi.org/10.1016/j.bjm.2017.08.004

36. Zaghi LL Jr, Lopes AD, Cordeiro FA, Colla IM et al (2018) Cryopreservation at $-75{ }^{\circ} \mathrm{C}$ of Agaricus subrufescens on wheat grains with sucrose. Braz J Microbiol 49:370-377

37. Colauto NB, Eira AF (1995) Effects of substrate containers on Pleurotus sajor-caju (Fr.) Singer mushroom production distribution. Energia na Agric 10:19-28

38. AOAC (2016) Association of official analytical chemists. Official methods of analysis of AOAC International (20th Edition). AOAC INTERNATIONAL, Gaithersburg

39. European Commission (2011) The European Parliament and Council. Regulation (EC) No. 1169/2011 of the European Parliament and of the Council of 25 October 2011 on the provision of food information to consumers. Off $\mathbf{J}$ Eur Union 304:L304/18-L304/63

40. Petropoulos S, Fernandes Â, Pereira C, Tzortzakis N et al (2019) Bioactivities, chemical composition and nutritional value of Cynara cardunculus L. seeds. Food Chem 289:404-412. https:// doi.org/10.1016/j.foodchem.2019.03.066

41. Barros L, Pereira C, Ferreira ICFR (2013) Optimized analysis of organic acids in edible mushrooms from Portugal by ultra fast liquid chromatography and photodiode array detection. Food Anal Methods 6:309-316. https://doi.org/10.1007/s12161-012-9443-1

42. Pires TCSP, Dias MI, Barros L, Calhelha RC et al (2018) Edible flowers as sources of phenolic compounds with bioactive potential. Food Res Int 105:580-588. https://doi.org/10.1016/j.foodres. 2017.11.014

43. Reis FS, Barros L, Martins A, Ferreira ICFR (2012) Chemical composition and nutritional value of the most widely appreciated cultivated mushrooms: an inter-species comparative study. Food Chem Toxicology 50:191-197. https://doi.org/10.1016/j.fct.2011. 10.056

44. Heleno SA, Barros L, Souza MJ, Martins A et al (2010) Tocopherols composition of Portuguese wild mushrooms with antioxidant capacity. Food Chem 119:1443-1450

45. Reis FS, Barreira JC, Calhelha RC, Van Griensven LJ et al (2014) Chemical characterization of the medicinal mushroom Phellinus linteus (Berkeley \& Curtis) teng and contribution of different fractions to its bioactivity. LWT 58:478-485. https://doi.org/10. 1016/j.lwt.2014.04.013

46. Abreu RMV, Ferreira ICFR, Calhelha RC, Lima RT et al (2011) Anti-hepatocellular carcinoma activity using human HepG2 cells and hepatotoxicity of 6-substituted methyl 3-aminothieno[3,2-b] pyridine-2-carboxylate derivatives: In vitro evaluation, cell cycle analysis and QSAR studies. Eur J Med Chem 46:5800-5806. https://doi.org/10.1016/j.ejmech.2011.09.029

47. Brand-Williams W, Cuvelier ME, Berset C (1995) Use of a free radical method to evaluate antioxidante activity. LWT 28:25-30

48. Rufino MSM, Alves RE, Brito ES, Morais SM et al (2007) Metodologia científica: Determinação da atividade antioxidante total em 
frutas pela captura do radical livre DPPH. Comunicado técnico Embrapa 127:1-4

49. Rufino MSM, Alves RE, Brito ES, Morais SM et al (2006) Metodologia científica: determinação da atividade antioxidante total em frutas pelo método de redução do ferro (FRAP). Comunicado Técnico Embrapa 125:1-4

50. Mattos LM, Morreti CL, Muniz LB, Silva EYY (2009) Protocolo de análise para determinação da atividade antioxidante total em hortaliças no sistema beta-caroteno/ácido linoleico. Comunicado Técnico Embrapa 68:1-5

51. Velioglu YS, Mazza G, Gao L, Oomah BD (1998) Antioxidant activity and total phenolics in selected fruits, vegetables and grain products. J Agric Food Chem 46:4113-4117

52. Barros L, Baptista P, Estevinho LM, Ferreira ICFR (2007) Wild and commercial as source of nutrients and nutraceuticals. Food Chem Toxicol 46:2742-2747

53. Vetter J, Crude RI (1993) digestible and indigestible protein in fruiting bodies of Pleurotus ostreatus. Z Lebensm Unters Forsch 197:427-428

54. Almeida SM, Uemo SH, Marcante RC, Yokota ME et al (2015) Iron bioaccumulation in mycelium of Pleurotus ostreatus. Braz J Microbiol 46:195-200

55. Yokota ME, Frison PS, Marcante RC, Jorge LF et al (2016) Iron translocation in Pleurotus ostreatus basidiocarps: production, bioavailability, and antioxidant activity. Genet Mol Res 15:1-10

56. Kalač P (2013) A review of chemical composition and nutritional value of wild-growing and cultivated mushrooms. J Sci Food Agric 93:209-218

57. Campos CS, Araujo LM, Minhoni MTA, Andrade MCN (2013) Centesimal composition and physical-chemistry analysis of the edible mushroom Lentinus strigosus occurring in the Brazilian Amazon. An Acad Bras Cienc 85:1537-1544. https://doi.org/ 10.1590/0001-3765201399412

58. Dávila GLR, Murillo AW, Zambrano FCJ, Suárez MH et al (2020) Evaluation of nutritional values of wild mushrooms and spent substrate of Lentinus crinitus (L.) Fr. Heliyon 6:e03502. https://doi.org/10.1016/j.heliyon.2020.e03502

59. Chang ST, Miles PG (2004) Mushrooms: cultivation, nutritional value, medicinal effect, and environmental impact, 2 nd edn. CRC, Boca Raton

60. Liu JH, Shang XD, Liu JY, Tan Q et al (2016) Changes in trehalose content, enzyme activity and gene expression related to trehalose metabolism in Flammulina velutipes under heat shock. Microbiology 162:1274-1285

61. Liu XM, Wu XL, Wei GAO, Qu JB et al (2019) Protective roles of trehalose in Pleurotus pulmonarius during heat stress response. J Integr Agric 18:428-437

62. Colla IM, Oliveira Filho OBQ, Freitas JDS, Bertéli MBD et al (2020) Mycelial biomass cultivation of Lentinus crinitus. Biosci J 36:2238-2246

63. Higashiyama T (2002) Novel functions and applications of trehalose. Pure Appl Chem 74:1263-1269

64. Richards AB, Krakowka S, Dexter LB, Schmid H et al (2002) Trehalose: a review of properties, history of use and human tolerance, and results of multiple safety studies. Food Chem Toxicol 40:871-898

65. Marim RA, Avelino KV, Halabura MI, Araújo NL et al (2020) Lentinus crinitus response to blue light on carbohydrate-active enzymes. Biosci J 36:924-931

66. Tang B, Zhang L, Xiong XP, Wang HJ et al (2018) Advances in trehalose metabolism and its regulation of insect chitin synthesis. Sci Agric Sin 51:697-707. https://doi.org/10.3864/j.issn. 0578-1752.2018.04.009
67. Gonçalves LM, Trevisol ETV, de Azevedo AVB, de Mesquita JF (2020) Trehalose synthesis inhibitor: a molecular in silico drug design. J Cell Biochem 121:1114-1125

68. Martirosyan DM, Singh J (2015) A new definition of functional food by FFC: what makes a new definition unique? Funct. Foods Helath Dis 5:209-223

69. Heleno SA, Barros L, Souza MJ, Martins A (2009) Study and characterization of selected nutrients in wild mushrooms from Portugal by gas chromatography and high performance liquid chromatography. Microchem J 93:195-199. https://doi.org/10. 1016/j.microc.2009.07.002

70. Haag M (2003) Essential fatty acids and the brain. Can J Psychiatry 48:195-203

71. Valentão P, Andrade PB, Rangel J, Ribeiro B et al (2005) Effect of the conservation procedure on the contents of phenolic compounds and organic acids in chanterelle (Cantharellus cibarius) mushroom. J Agr Food Chem 53:4925-4931

72. Carvajal AESS, Koehnlein EA, Soares AA, Eler GJ et al (2012) Bioactives of fruiting bodies and submerged culture mycelia of Agaricus brasiliensis (A. blazei) and their antioxidant properties. LWT 46:493-499

73. Mocan A, Fernandes A, Barros L, Crisan G et al (2018) Chemical composition and bioactive properties of the wild mushroom Polyporus squamosus (Huds.) Fr: a study with samples from Romania. Food Funct 9:160-170

74. Barros L, Dueñas M, Ferreira IC, Baptista P et al (2009) Phenolic acids determination by HPLC-DAD-ESI/MS in sixteen different Portuguese wild mushrooms species. Food Chem Toxicol 47:1076-1079

75. Palacios I, Lozano M, Moro C, D’Arrigo M et al (2011) Antioxidant properties of phenolic compounds occurring in edible mushrooms. Food Chem 128:647-678

76. Guzman JD (2014) Natural cinnamic acids, synthetic derivatives and hybrids with antimicrobial activity. Molecules 19:19292-19349

77. Wu X, Cheng J, Wang X (2017) Dietary antioxidants: potential anticancer agents. Nutr Cancer 69:521-533

78. Lopez-Bucio J, Nieto-Jacobo MF, Rodriguez VR (2000) Organic acid metabolism in plants: from adaptive physiology to transgenic varieties for cultivation in extreme soils. Plant Sci 160:1-13

79. Seabra RM, Andrade PB, Valentao P, Fernandes E et al (2006) Anti-oxidant compounds extracted from several plant materials. Biomater Aquat Terr Organ 2006:115-174

80. Boonsong S, Klaypradit W, Wilaipun P (2016) Antioxidant activities of extracts from five edible mushrooms using different extractants. Agric Nat Resour 50:89-97

81. Reis FS, Barros L, Calhelha RC, Cirić A et al (2013) The methanolic extract of Cordyceps militaris (L.) Link fruiting body shows antioxidant, antibacterial, antifungal and antihuman tumor cell lines properties. Food Chem Toxicol 62:91-98

82. Elmastas M, Isildak O, Türkekul I, Temur N (2007) Determination of antioxidant activity and antioxidant compounds in wild edible mushrooms. J Food Compos Anal 20:337-345. https://doi.org/10. 1016/j.jfca.2006.07.003

83. Arora R, Yates C, Gary BD, McClellan S et al (2014) Panepoxydone targets NF-kB and FOXM1 to inhibit proliferation, induce apoptosis and reverse epithelial to mesenchymal transition in breast cancer. PLoS ONE 9:e98370. https://doi.org/10.1371/journ al.pone. 0098370

84. Joseph TP, Chanda W, Padhiar AA, Batool S et al (2017) Preclinical evaluation of the antitumor activities of edible and medicinal mushrooms: a molecular insight. Integr Cancer Ther 17:200-209. https://doi.org/10.1177/1534735417736861 
85. Pan R, Bai X, Chen J, Zhang H et al (2019) Exploring structural diversity of microbe secondary metabolites using OSMAC strategy: a literature review. Front Microbiol 10:1-20. https://doi.org/ 10.3389/fmicb.2019.00294

86. Rahman A (2019) Frontiers in natural product chemistry. Bentham Books Imprint, London

87. Satyanarayana T, Deshmukh SK, Deshpande MV (2019) Advancing frontiers in mycology and mycotechnology basic and applied aspects of fungi. Springer, Singapore
88. Calhelha RC, Falcão S, Queiroz MJRP, Vilas-Boas M (2014) Cytotoxicity of Portuguese propolis: the proximity of the in vitro doses for tumor and normal cell lines. BioMed Res Int 2014:1-7. https://doi.org/10.1155/2014/897361

Publisher's Note Springer Nature remains neutral with regard to jurisdictional claims in published maps and institutional affiliations. 